\title{
Contribution of women's fisheries substantial, but overlooked, in Timor-Leste
}

\author{
Alexander Tilley (1), Ariadna Burgos, Agustinha Duarte, \\ Joctan dos Reis Lopes, Hampus Eriksson, David Mills
}

Received: 27 April 2019/Revised: 6 June 2019/Accepted: 31 March 2020/Published online: 8 May 2020

\begin{abstract}
A greater understanding of gendered roles in fisheries is necessary to value the often-hidden roles that women play in fisheries and households. We examine women's contributions to household food and income using focus group discussions, market surveys, and landings data in six communities in Timor-Leste. Women were actively fishing more days per month than men. Gleaning was the most frequent activity and $100 \%$ of trips returned with catch for food and/or income. Mollusc and crab catches were common and exploitation appeared targeted on a dynamic reappraisal of changing food values and changing estimates of group needs. With as many as $80 \%$ of households in coastal areas involved in fishing, and at least $50 \%$ of women fishing, this highlights the current lack of women's engagement as a critical gap in fisheries management approaches. The current androcentric dialogue limits social-ecological understanding of these systems and the potential for their effective stewardship.
\end{abstract}

Keywords Coastal livelihoods · Food security ·

Gender · Gleaning · Poverty $\cdot$ Women

\section{INTRODUCTION}

There is growing recognition that small-scale fisheries (SSF) are an irreplaceable source of food and nutrition to millions of poor people around the world, particularly in coastal regions (Golden et al. 2016; Hicks et al. 2019; Österblom et al. 2020). Locally caught aquatic foods (i.e. finfish, seaweeds, molluscs like cockles and octopus, and

Electronic supplementary material The online version of this article (https://doi.org/10.1007/s13280-020-01335-7) contains supplementary material, which is available to authorized users. crustaceans like crabs and crayfish) are an accessible yet under-recognised source of bioavailable micronutrients (Bogard et al. 2017). And, even when only conducted on a seasonal or part-time basis, these fishing activities are often a critical element in household economies (Béné et al. 2016; Mills et al. 2017). Fisheries in many countries are data blind to women's contributions (Mills et al. 2011; Harper et al. 2020), which perpetuates relative or total exclusion from management, and has in several instances led to women's isolation from the resource on which they depend. Awareness of women's fisheries catch and effort is a first, but alone not an adequate step, to include women's voices and consideration of their activities in resource management decisions (Kleiber et al. 2014). Gender equal fisheries policy that explicitly strengthens food and nutrition security, depends on our understanding of the magnitude and variability of fisheries' contributions, and the gendered factors that affect the distribution, access, and use of fisheries resources (Fröcklin et al. 2014; Weeratunge et al. 2014; de la Torre-Castro et al. 2017). Ultimately, research that highlights the relationship between fisheries and poverty, the welfare function of fisheries and the role of fisheries in local food security are as important for policy development as fisheries production information (Allison and Mills 2018).

Open access, low-entry-cost fishing activities conducted by women that contribute small but regular input often represent a crucial food security activity for isolated communities (Hockey et al. 1988; Quinn and Davis 1997; Beitl 2011). This is particularly relevant in the small-island developing states, where reliance on coastal resources is high. In American Samoa, women and child fishers landed $32 \%$ of the annual catch from inshore environments, $68 \%$ of which came from gleaning (Hill 1978): the manual collection of food in shallow intertidal areas (Chapman 
1987). Research on gleaning provides useful insight into the dynamics of poverty and resource reliance in fishing communities (Charles 2011).

Timor-Leste is a small-island developing state with at least $60 \%$ of the population being food insecure and more than $50 \%$ of children stunted due to micronutrient deficiency (Molyneux et al. 2012; von Grebmer et al. 2018). Foraging for wild food is a key coping strategy to food insecurity (da Costa et al. 2013) and access to marine resources drive large differences in per capita fish consumption between inland and coastal areas (AMSAT International 2011). Androcentrism in national fisheries management is entrenched. While currently under revision, policy, law and data collection systems have largely ignored fisheries that are not conducted from a boat, thereby excluding most women fishers. Hence, the direct and indirect roles women (and children) play in fisheries are not well understood at all. There are very few sexdisaggregated data with which to assess activities and contributions, and very few women are involved in decision-making at national and municipal levels (López-Angarita et al. 2019). In this paper, we aim to characterise women's fisheries in the context of SSF in Timor-Leste to gain a better understanding of who fishes, where and with what, the drivers affecting fishing activities and the role that fishing and fishing-related activities play at the household level. In doing so, we attempt to highlight the unrecognised contribution that women and their fisheries catches represent across Timor-Leste, and reflect on the impact this may have on management and development priorities.

\section{MATERIALS AND METHODS}

\section{Focus group discussions and fisher interviews}

Focus group discussions (FGD) formed of 5-15 women fishers were carried out in 9 communities throughout Timor-Leste (Fig. 1) during February and March 2017 and women were interviewed individually after data collection for specific clarifications. Name, age and household size were recorded for each participant. Respondents were asked to describe seasonal patterns of marine resource use, gear types, target species, market prices and ecological trends. An inventory of species considered important for food or commercial ornamental trade by coastal communities was developed in December 2017 and August 2018 on Atauro Island by surveying gleaners catches, household shell waste dumps and conducting market surveys $(n=5)$. Local names, as well as the local ecological knowledge regarding the different species, were recorded. Taxonomic identification of species was conducted at the marine invertebrate collection of the French Museum of Natural History in Paris. Finfish and crustacean species landed were identified by trained data collectors referencing a photographic list of 130 known local species. Unknown species were listed as such and submitted along with a photograph.

\section{Fishing activities}

Findings from interviews and focus group discussions (FGD) across all communities informed the structure of a fishing activities diary and gleaning data collection form (Appendix S1), which was distributed to FGD participants in 6 of the communities (Fig. 1). All of these women were asked to record their daily fishing activities and income for at least one continuous two-week period between March and August 2017. For each fishing activity recorded, women noted the date, the method/gear (hand line, net, spear or gleaning), if the catch was consumed by the household or sold, or both, and the total income earned from catch sales per fishing method.

Women fishers' activity coefficient (AC) by location was estimated to compare with vessel activity coefficients from men's fishing reported in (Tilley et al. 2019b), by calculating the proportion of days fished from the total number of days in the sampling period. This was then reported as the number of days per month fishing. Income was not normally distributed so differences in income according to location and fishing method were tested using a Wilcoxon test with Chi-squared approximation.

For gleaning activities, fishers used an additional form to record a greater level of detail on species groups that were landed, as well as the income from these groups, and trip duration. The form provided for gleaning activities was prepopulated with commonly targeted gleaning species groups identified by FGD participants. These were: fish, moray eels (separated by respondents, so this categorisation was maintained), octopus, squid, "snails" (cockles, clams, mussels, oysters, snails, winkles and abalones), crabs, shrimps and other. Income was only recorded per trip, and not per species group so it was not possible to evaluate species market price information from landings data. This information was gathered through interviews and FGDs. As a measure of relative abundance or commonness of each species (i) in the catch composition by location, an index of relative importance (IRI) (adapted from Kolding 1989) was used:

$\% \mathrm{IRI}_{i}=\frac{\% N_{i} \% F_{i}}{\sum_{j=1}^{6}\left(\% N_{j} \% F_{j}\right)} \times 100$

where $\% N_{i}$ is percentage number of each species group $i$ of the total catch and $\% F_{i}$ is the percentage frequency of 


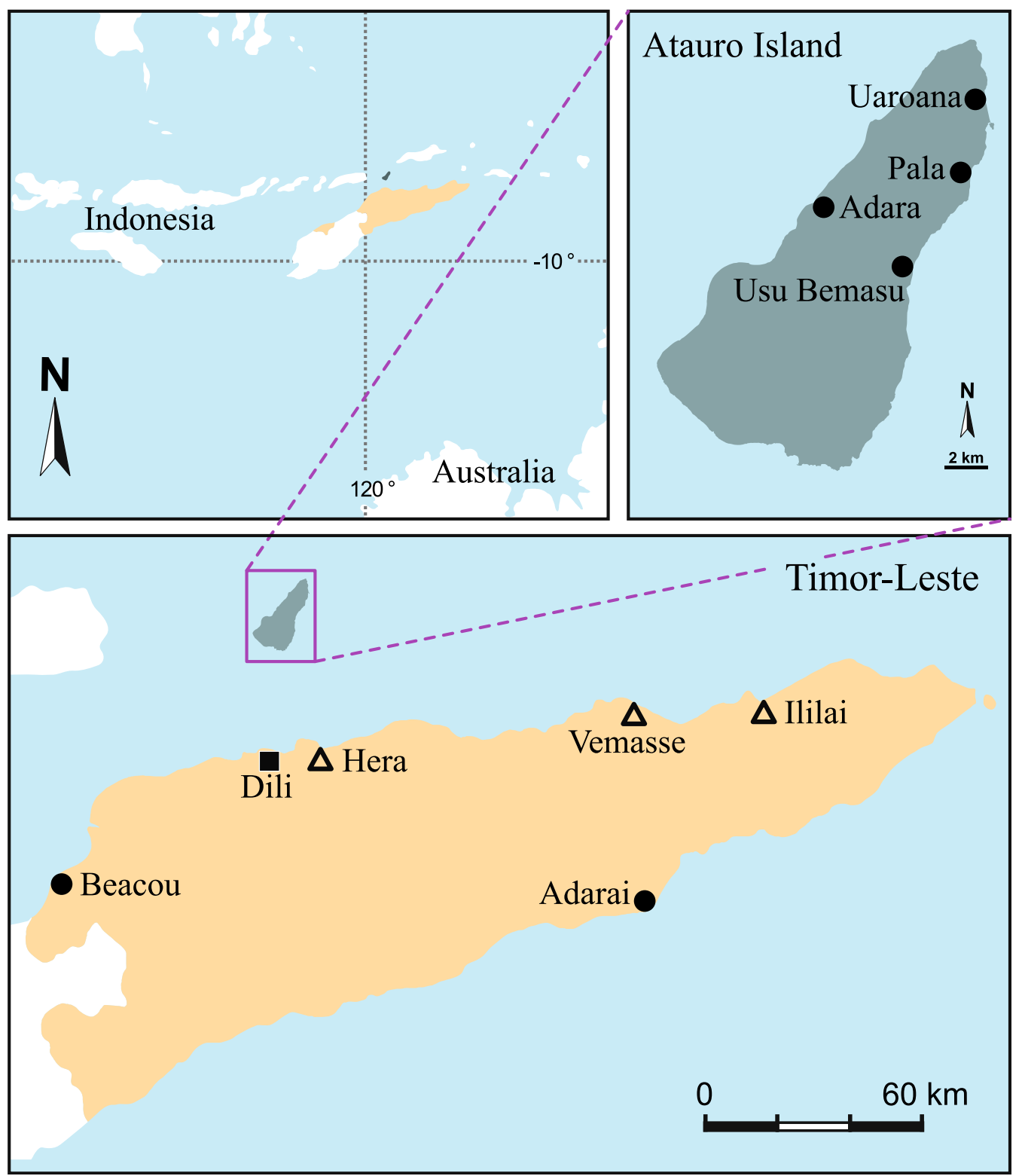

Fig. 1 Map of community sites surveyed throughout Timor-Leste. Solid circles represent communities where focus group discussions and fishing diary data were collected. Hollow triangles represent communities where only focus group discussions were conducted

occurrence of each species in the total number of samples, summed over all species groups from $j=1$ to 6 .

\section{RESULTS}

\section{Focus group discussions and fisher interviews}

Focus group discussions indicated that women actively fished using one or more gear types in 9 out of 10 locations. Only the site of Vemasse in Baucau reported that women do not actively fish or glean. Most gleaners stated that they went gleaning every day for different purposes (food, household income, and hobby). There was variation in gleaning techniques and target species. Gleaning trips would target one species or group of species, using various combinations of gears and techniques (Table 1). Fishing classified as gleaning (meti) implies manual collection but may include carrying a hooked metal bar for prying up or breaking open rocks or pulling organisms from crevices (Fig. 2), a small basket for trapping (roso), and plant-based toxins for stunning or flushing out reef dwelling organisms. The creel carried to collect the catch is most often a basket woven from palm fronds (bote) (Fig. 2). Women rely on environmental signals, local knowledge and active communication to select gleaning localities and target species. 
Thus, keeping track of other gleaners' activities by personal observation or information exchange is fundamental to maximise gleaning catches. While gleaning, women pay particular attention to the disturbance and distribution of rocks and reef elements, the marks from iron bars on the reef, and freshness of sand footprints. Exchange of information regarding the village's fishing dynamics takes place on-site, while gleaning, but also at any time during the day.

In most locations, gleaning activities were timed around the tidal cycle. The most popular times to glean were the early morning and evening. When the low tide occurs outside of these times, gleaning is more arduous due to high temperatures, sun exposure, and lower catchability due to finfish and invertebrates seeking deeper refuge in reef crevices. The number of gleaners at all sites was observed to visibly increase around the spring tides due to the greater surface area of reef exposed.

Interviews identified different uses according to five common intertidal environments: (i) rocky shore, where gleaners target small gastropods such as Nerites (snails), Patella (true limpets), and crab species; (ii) gravelly beach (i.e. a mix of coral rubble, gravel, fine sand and coarse sands) where an economically important bivalve, Asaphis violascens is found; (iii) seagrass beds, which provide habitat for finfish and molluscs while supporting the cultivation of seaweed; (iv) reef flat with the highest diversity of targeted species; and (v) forereef, where finfish, large molluscs such as giant clams, and valuable gastropods for decorative and handcraft purposes (e.g. Charonia tritonis, Turbo marmoratus, Rochia nilotica) are found (Fig. 3). No mangroves were present in the study villages where interviews were undertaken, so they were not identified as habitat in the exercise.

\section{Species market prices}

In Atauro, women in interviews reported the bivalve $A$. violascens provided the most income, along with a few small gastropods whose shells were used to make necklaces and sold to Atauro tourists. Gathering of A. violascens requires digging up to $20 \mathrm{~cm}$ in gravel substrate near the waterline (see Fig. 2, left panel)). Two hours of A. violascens collection typically yielded between 100 and 150 shells, and a dish containing 20-30 uncooked specimens was sold at USD \$1. Assuming an average wet, shelled weight of $6 \mathrm{~g}$, one sale portion would be between 120 and $180 \mathrm{~g}$, indicating a sale price of between $\$ 5.50$ and $\$ 8.30$ per $\mathrm{kg}$ (Table 2). This is notably higher than the average price of fish foods from men's landings $(\$ 2.13 / \mathrm{kg})$ as reported in Tilley et al. (2019b). However, many transactions are based on 'eyeballed' estimations or non-standard measures such as handfuls, so accurate prices per weight are not available. The most coveted edible species at the household level were Turbo setosus, Turbo chrysostomus, A. violascens and giant clams Tridacna spp. and Hippopus hippopus.

\section{Fishing activities}

Activity and catch data were recorded for 825 fishing trips by 32 women fishers from 6 communities between March and June 2017. Women participants ranged in age from 21 to 66 years $($ mean $=38.3)$ (Table 3$)$. The average household size across the 6 communities was $7.0 \pm 2.0$ persons (compared to the national average of 5.8 (Government of Timor-Leste 2015), with the largest household size of 16 people reported in Beacou, the community with the highest mean occupancy $(10.9 \pm 1.8)$. During the sampling period in each location, the activity coefficient in days fished per month varied between 9 and 29 days, with a mean of 20 days per month across all sites (Table 3 ).

Across all locations combined, gleaning was the most frequent fishing activity among women, representing $40 \%$ of all trips (Table 4). Different fishing methods were used on the same trip, apart from Adarai where women only conducted gleaning. Women also identified and recorded seaweed cultivation as a 'fishing activity', but this was excluded from the analysis of fishing activities. Women fishers did not report any fishing activities with cast nets (dai) or set traps (bubur) during the sampling period; however, small hand traps made of woven baskets (roso) are used in the gleaning fishery. Across all fishing activities, less than $1 \%$ of trips returned with no catch. The zero catch rate reported from men's fisheries landings in the same communities $(N=2655)$ is $13 \%$ (Tilley et al. 2019b).

\section{Gleaning}

Gleaning had a $100 \%$ catch rate: every trip returned with something to eat, sell or both. The average duration of a gleaning trip was $3.0 \pm 0.5$ hours. $71 \%$ of gleaning trips provided household food only, $14 \%$ provided income only $($ mean $=\$ 2.16$ (3.92), and 14\% provided both income and food.

Shelled molluscs (bivalves and gastropods) were the most numerous species group in gleaning catches at all sites except Beacou, where fish dominated. Fish were the most important (IRI) species group across all sites except Uaroana (Table 5), where squid had the highest IRI. Molluscs were considerably more abundant in women's catches from the eastern side of Atauro Island (Biqueli, Uaroana) and Adarai (where only gleaning was conducted), than other sites. Squid was only present in catches from two sites, being the most important group from Uaroana (25\% IRI) and more rarely landed in Beacou (11\% IRI). Octopus was relatively rare in catches from all sites, representing 
Table 1 Main species captured by women's nearshore fishing activities in Timor-Leste, and their uses

\begin{tabular}{|c|c|c|}
\hline Group & Main species & Usage \\
\hline Fish & $\begin{array}{l}\text { Reef and seagrass dwelling herbivores } \\
\text { and grazers such as rabbitfishes and } \\
\text { spinefoots (Siganidae), wrasses } \\
\text { (Labridae and e.g. Novaculichthys } \\
\text { macrolepidotus), surgeonfishes \& } \\
\text { unicornfishes (Acanthuridae), } \\
\text { and parrotfishes (Scaridae and e.g. } \\
\text { Leptoscarus vaigiensis) }\end{array}$ & $\begin{array}{l}\text { Household consumption and income. Species are sold fresh or dried. Drying is common } \\
\text { in remote areas (due to transportation issues/costs) } \\
\text { In Atauro, spinefoot and wrasse species are sold grilled at the weekly market (to } \\
\text { domestic tourists) } \\
\text { Species of all sizes are captured, with children and youth specialising in targeting small- } \\
\text { bodied species and juvenile fish occurring in the very shallow reef, rockpools and } \\
\text { seagrass habitats using a small handheld Hawaiian sling comprised of a stiff metal } \\
\text { wire powered by an elastic band (kilat ki' }{ }^{\prime} \text { ) (Fig. } 4 \text { ) }\end{array}$ \\
\hline Moray & $\begin{array}{l}\text { Muraenidae (e.g. Enchelynassa canina, } \\
\text { Echidna nebulosa, Gymnothorax spp.) }\end{array}$ & $\begin{array}{l}\text { Moray eels are a low-value species that are generally only consumed by the fisher } \\
\text { households. However, they are relatively easy to catch as they are found in tidal pools } \\
\text { hunting for stranded fish and invertebrates }\end{array}$ \\
\hline Shrimp & $\begin{array}{l}\text { Palaemon concinnus, Metapenaeus ensis, } \\
\text { Psalidopus huxleyi, Metapenaeopsis } \\
\text { spp., Metapenaeus spp. }\end{array}$ & $\begin{array}{l}\text { Most species of shrimps and prawns are sought after, either sold during market days, } \\
\text { used to prepare shrimp powder, or eaten locally to flavour dishes. Brackish species are } \\
\text { fished seasonally with hand nets in river mouths or with set beach seines. Shallow } \\
\text { water and tidal shrimp are commonly targeted by small children by overturning rocks } \\
\text { at low tide. }\end{array}$ \\
\hline Crabs & $\begin{array}{l}\text { Portunidae, Scylla serrata, Portunus } \\
\text { armatus }\end{array}$ & $\begin{array}{l}\text { Most species of small reef crabs such as blue swimmer crabs are consumed at the } \\
\text { household level. Large crabs (mangrove mud crabs Scylla spp.) are sold locally. } \\
\text { These are rare from Atauro where very little mangrove area exists }\end{array}$ \\
\hline $\begin{array}{l}\text { Shelled } \\
\text { molluscs }\end{array}$ & $\begin{array}{l}\text { In sampling of Atauro Island alone, } 53 \\
\text { species of molluscs from } 31 \text { families } \\
\text { were recorded ( } 40 \text { gastropods, } 10 \\
\text { bivalves and } 3 \text { cephalopods) (Table S1) }\end{array}$ & $\begin{array}{l}92 \% \text { of all species listed were edible, including all bivalves. The flesh of bivalves and } \\
\text { gastropods are used for food at the household level. Only a few species are gathered } \\
\text { to be sold fresh for consumption such as Asaphis violascens and Tridacna squamosa. } \\
\text { Cypraea tigris, Cypraecassis rufa and Pinctada margaritifera are eaten at the } \\
\text { household level and their shell is sold. } \\
\text { Three gastropods (Charonia tritonis, Mauritia arabica, Monetaria caputserpentis) and } \\
\text { one cephalopod (Nautilus pompilius) were not consumed but their empty shell is sold } \\
\text { to tourists (e.g. } \sim \$ 25 / \text { shell for Charonia tritonis). Tectus niloticus }(\sim \$ 5-12 / \text { shell) } \\
\text { and Turbo marmoratus are also sought after for adornments, decoration or jewellery. } \\
84 \% \text { of bivalves and gastropods species identified were exclusively for home } \\
\text { consumption }\end{array}$ \\
\hline Octopus & $\begin{array}{l}\text { Octopus cyanea, Callistoctopus ornatus, } \\
\text { Octopus spp. }\end{array}$ & $\begin{array}{l}\text { Octopus was caught using an iron rod to prod and probe reef crevices (Fig. } 2 \text { ). The price } \\
\text { of octopus varied according to size but was consistently one of the most valuable of } \\
\text { all species captured across all fisheries, with a mean market price of } \$ 4.55 / \mathrm{kg} \text {. } \\
\text { Octopus is an important source of income (prioritised for sale) and is sold sun-dried, } \\
\text { smoked or fresh. In Adarai octopus is baked in palm leaves (saboko) for social } \\
\text { gatherings. Small individuals are sometimes used as bait }\end{array}$ \\
\hline Squid & $\begin{array}{l}\text { Loliginidae (e.g. Sepioteuthis lessoniana, } \\
\text { Sepioteuthis spp.) }\end{array}$ & $\begin{array}{l}\text { Squid is prioritised for sale. It is caught using a hand line and sold fresh or smoked } \\
\text { (never observed as a dried product) }\end{array}$ \\
\hline Sea urchin & Echinoidea & $\begin{array}{l}\text { Urchins are gathered in seagrass areas for consumption. The roe is scooped out and } \\
\text { cooked (steamed), or the urchin is baked whole directly on the coals then cracked } \\
\text { open to consume. }\end{array}$ \\
\hline $\begin{array}{l}\text { Peanut } \\
\text { worms }\end{array}$ & Sipunculida & $\begin{array}{l}\text { Sipunculid worms are dug out of sand in seagrass areas. The rough exterior is abraded } \\
\text { off and the inner flesh is boiled, fried or dried for consumption }\end{array}$ \\
\hline
\end{tabular}

$17 \%$ of individuals caught in Beacou and $21 \%$ in Adarai. These two sites, perhaps correspondingly were the sites with the highest mean income from gleaning. The restricted distribution of squid catches to only two sites is likely to be due to the method by which they are caught (jigging) generally requiring access to a boat, which may not be desirable or available to women (Fig. 4).

\section{Income}

The highest-earning fishing activities were gill netting and handlining, showing similar income levels (USD \$ $3.31 \pm 2.69(N=180)$ and $\$ 3.21 \pm 1.58(N=245)$ per trip, respectively) (Table 6). The difference in income by location was significant $\left(\chi^{2}=5, P<0.0001\right)$, and by 


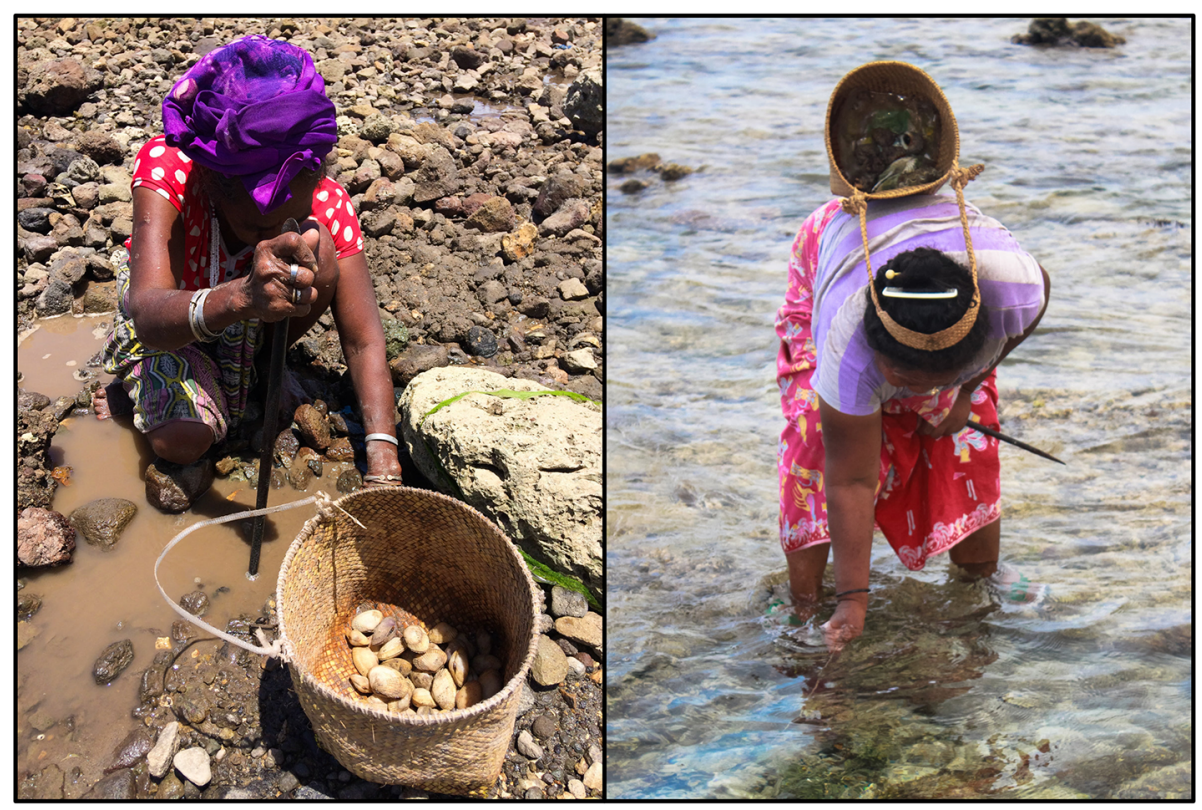

Fig. 2 Women gleaners: Digging for cockles Asaphis violascens (left pane) and probing for octopus at low tide (right pane). Photos by A. Tilley

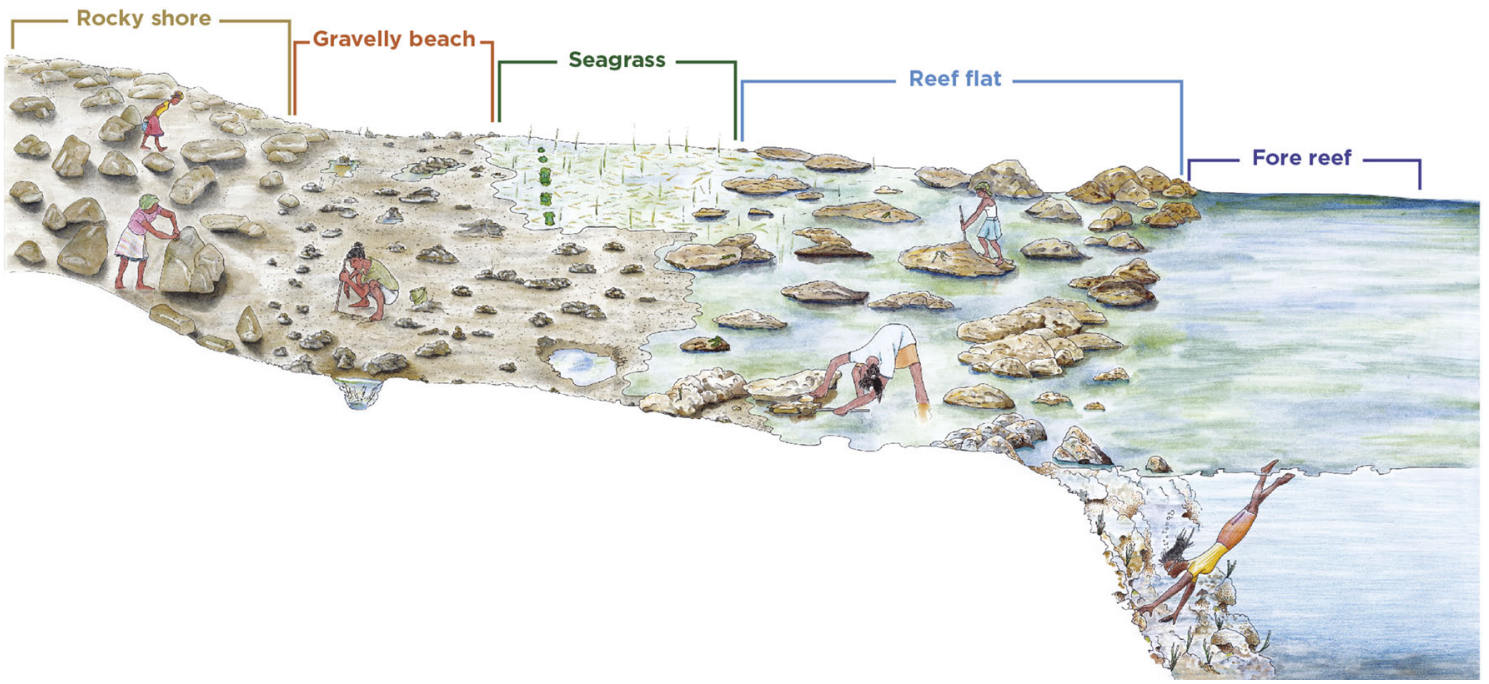

Fig. 3 Sketch of the zonation of fishing/gleaning activities according to the ecological distribution of species. The gravelly beach is a mix of coral rubble, gravel, fine sand and coarse sands (c) A. Burgos and L. Billault -LRD

fishing activity (Wilcoxon, $\chi^{2}=8.3328,3, P=0.0396$ ). The highest earnings per trip across all activities seen from Adarai gleaners (Table 6). Given the isolation of Adarai on Timor-Leste's south coast (Fig. 1), this is likely to reflect high volumes rather than high market prices. Cumulative income from all activities is more indicative of incomes from a variety of fishing methods (Fig. 5). Mean ( \pm SD) women fisher income per trip across all activities and locations was $2.21( \pm 3.91)$.

\section{DISCUSSION}

In Timor-Leste, women are commonly the largest group of resource users in the intertidal reef and seagrass areas, as has been observed elsewhere in the Pacific (Chapman 1987; Harper et al. 2013; Lambeth et al. 2014). The importance of women's fishing activities to income varied by location, but focus group participants indicated that some form of fishing was conducted by men and women 
Table 2 Prices per weight or number of individuals for consumed species groups at 6 sites across Timor-Leste, reported by women fishers in interviews and focus groups. Empty cells reflect no data available or the species group is not commonly caught or sold in the area

\begin{tabular}{|c|c|c|c|c|c|c|}
\hline Species & Octopus & Fish & $\begin{array}{l}\text { Shelled } \\
\text { molluscs }\end{array}$ & Shrimp & Squid & Crab \\
\hline Adara & $1 \mathrm{~kg}=\$ 6400 \mathrm{~g}=\$ 1.5$ & $600 \mathrm{~g}=\$ 1$ & & - & - & - \\
\hline Adarai & $1.5 \mathrm{~kg}=\$ 5$ & $\begin{array}{l}5 \text { fish }=\$ 1 \\
\text { Morays \$2-4 }\end{array}$ & & $7-10$ indiv. $=\$ 3$ & - & 2 crabs $=\$ 3$ \\
\hline Beacou & 5 indiv. $(\sim 300 \mathrm{~g})=\$ 2$ & $30-40$ indiv. $(<5 \mathrm{~cm})=\$ 1$ & & $\sim 30$ indiv.$=\$ 1.50$ & 2 indiv. $=\$ 2$ & 7 indiv. $=\$ 1$ \\
\hline Beloi & $1 \mathrm{~kg}=\$ 8400 \mathrm{~g}=\$ 2.5$ & $600 \mathrm{~g}=\$ 1$ & $\$ 5.50-\$ 8.30 / \mathrm{kg}^{\mathrm{a}}$ & - & - & - \\
\hline Biqueli & $1 \mathrm{~kg}=\$ 7400 \mathrm{~g}=\$ 2$ & $600 \mathrm{~g}=\$ 1$ & & - & - & - \\
\hline Uaroana & $1 \mathrm{~kg}=\$ 7400 \mathrm{~g}=\$ 2$ & $600 \mathrm{~g}=\$ 1$ & & - & 2 indiv. $(\sim 600 \mathrm{~g})=\$ 4$ & - \\
\hline
\end{tabular}

${ }^{\mathrm{a} B e l o i}$ is the focal market centre for all products being sold on Atauro Island, so the price of shelled molluscs elsewhere is likely to be substantially lower

Table 3 Number of women fishers collecting data, number of trips, activity coefficient (AC) and demographic data from 6 sites in Timor-Leste

\begin{tabular}{lcclllr}
\hline Site & $N$ fishers & $N$ trips & Sampling dates & AC (days/month) & Mean age $( \pm$ SD) & Mean Household Size $( \pm$ SD) \\
\hline Adara & 8 & 293 & $27 / 3-13 / 4 / 17$ & 19 & $37.2( \pm 11.6)$ & $6.1( \pm 2.2)$ \\
Adarai & 3 & 34 & $11-23 / 5 / 17$ & 28 & $48.0( \pm 9.2)$ & $8.7( \pm 5.5)$ \\
Beacou & 4 & 84 & $24 / 4-11 / 5 / 17$ & 22 & $45.7( \pm 14.6)$ & $10.9( \pm 1.8)$ \\
Beloi & 5 & 49 & $22 / 3-11 / 4 / 17$ & 13 & $45.1( \pm 10.6)$ & $6.5( \pm 3.9)$ \\
Biqueli & 6 & 125 & $23 / 3-1 / 4 / 17$ & 29 & $35.9( \pm 5.8)$ & $5.3( \pm 1.7)$ \\
Uaroana & 6 & 240 & $15 / 5-24 / 6 / 17$ & 9 & $34.4( \pm 14.6)$ & $7.4( \pm 1.8)$ \\
Total/mean & 32 & 825 & - & 20 & $38.3( \pm 12.8)$ & $7.1( \pm 3.0)$
\end{tabular}

Table 4 Fishing activities undertaken by women in each location shown as a proportion of the total number of trips by location

\begin{tabular}{lcccc}
\hline & $\begin{array}{l}\text { Gleaning } \\
(\%)\end{array}$ & $\begin{array}{l}\text { Handline } \\
(\%)\end{array}$ & $\begin{array}{l}\text { Netting } \\
(\%)\end{array}$ & $\begin{array}{l}\text { Spearfishing } \\
(\%)\end{array}$ \\
\hline Adara & 38 & 26 & 26 & 10 \\
Adarai & 100 & 0 & 0 & 0 \\
Beacou & 52 & 27 & 17 & 4 \\
Beloi & 14 & 78 & 4 & 4 \\
Biqueli & 38 & 31 & 17 & 14 \\
Uaroana & 35 & 29 & 28 & 8 \\
Grand total & 40 & 30 & 22 & 8 \\
\hline
\end{tabular}

in $\sim 80 \%$ of households in the community. Consistent with findings from Tuvalu (Lambeth et al. 2014), many women reflected on their gleaning activity to be a social activity unto itself, or a hobby. An opportunity to spend time and talk with family and friends while being active. However, respondents agreed across all sites about the importance of gleaning during periods of low crop and horticulture production. August was mentioned as a time when gleaning was particularly plentiful and productive, corroborating findings of Mills et al. (2017) that seasonal winds during this period limit favourable fishing days and account for a dip in ('men's') SSF landings.
It is often observed that fishing serves as a buffer to natural hazards and livelihood shocks for the poor (Béné 2003; Eriksson et al. 2017), providing gathered foods from open-access systems to fill the subsistence "gap" until conditions improve (Luomala 1980; Chapman 1987). Increases in gleaning and collecting are tied closely to economic crises (Gillett 2009), where low cost, non-vessel fishing methods with a high value-added ratio can bring much needed relative revenues (Gillett 2009). However, despite the short sampling period of detailed activity diaries and gleaning catch, women participants in our study were frequent and consistent users of the marine environment. Catch volumes are lower on average than landings from men's fisheries, but the $\sim 99 \%$ success rate of women's fishing trips, compared to men's trip catch rate of $87 \%$ (Tilley et al. 2019b), is substantial. Furthermore, our activity coefficient data suggest that women fish more regularly than men, with $\sim 20$ days fishing per month compared to a mean activity level of $\sim 15$ days per month for men (Tilley et al. 2019b).

The $71 \%$ of landings reported as solely for consumption appear to support the subsistence narrative of gathered foods for food security. Interestingly, only $14 \%$ of landings were reported as being for both food and income, which might suggest that some fishers glean more determinedly than others, rather than returning with whatever they catch 
Table 5 Index of relative importance of species groups landed in women fishers' gleaning trips in Timor-Leste. Proportional importance sums per site

\begin{tabular}{lrlllclc}
\hline & $\begin{array}{l}\text { Crab } \\
(\%)\end{array}$ & $\begin{array}{l}\text { Moray } \\
(\%)\end{array}$ & $\begin{array}{l}\text { Shells } \\
(\%)\end{array}$ & $\begin{array}{l}\text { Fish } \\
(\%)\end{array}$ & $\begin{array}{l}\text { Octopus } \\
(\%)\end{array}$ & $\begin{array}{l}\text { Shrimp } \\
(\%)\end{array}$ & $\begin{array}{l}\text { Squid } \\
(\%)\end{array}$ \\
\hline Adara & 19 & 5 & 29 & 43 & 4 & 0 & 0 \\
Adarai & 4 & 2 & 16 & 34 & 21 & 3 & 0 \\
Beacou & 5 & 2 & 8 & 44 & 17 & 15 & 11 \\
Beloi & 11 & 1 & 23 & 46 & 4 & 16 & 0 \\
Biqueli & 5 & 3 & 27 & 41 & 13 & 11 & 0 \\
Uaroana & 1 & 1 & 20 & 23 & 9 & 20 & 25 \\
\hline
\end{tabular}

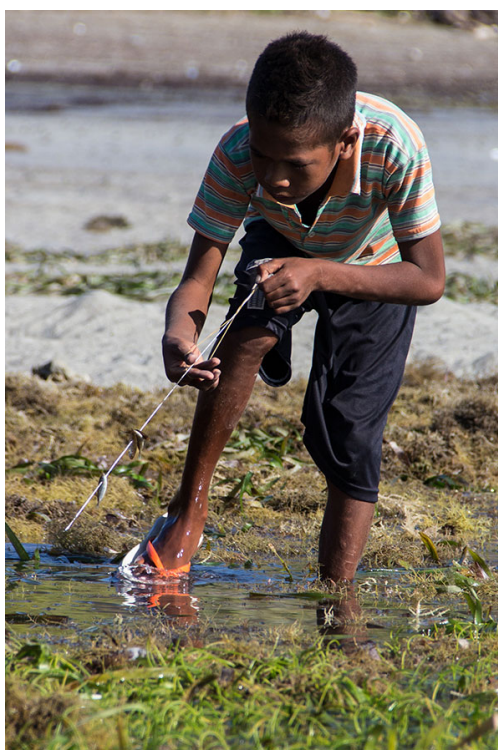

Fig. 4 A Timorese boy fishing in a seagrass flat with a small hawaiian sling (kilat ki'ik). Photo by Holly Holmes

and then attempting to sell it. However, these results are insufficient to make conclusions. Mollusc and crab species represent a nutritious element of Timorese subsistence diets, but only a small number of species are targeted for commercial purposes. 84\% of bivalves and gastropods species were exclusively for home consumption and played an important role to secure household protein, particularly in times of shortage and bad weather. They are available throughout the year and their distribution is relatively predictable (Thomas 2007), so decisions regarding their harvest are not necessarily determined by availability, but rather rely upon continuous tallying and assessment of all potential food resources; the dynamic reappraisal of changing food values and ease of procurement; as well as the changing estimates of group needs (Waselkov 1987). Crabs and shelled molluscs play an important role in food security, and gleaners are the primary agents in monitoring
Table 6 Income rates of women's fisheries activities represented by mean income in USD \$ per trip by location and gear type

\begin{tabular}{llllll}
\hline Site/gear & Gleaning & Handline & Netting & Spearfishing & Mean \\
\hline Adara & 0.81 & 0.72 & 2.30 & 0.52 & 1.25 \\
Adarai & 8.86 & - & - & - & 8.86 \\
Beacou & 4.27 & 5.87 & 2.29 & 3.33 & 4.39 \\
Beloi & 2.00 & 0.76 & - & - & 0.76 \\
Biqueli & 2.21 & 3.44 & 5.95 & 6.17 & 4.06 \\
Uaroana & 1.72 & 1.62 & 2.29 & 1.37 & 1.84 \\
Mean & 2.16 & 1.90 & 2.71 & 2.23 & 2.22 \\
SD & 3.92 & 3.81 & 3.91 & 4.18 & 3.91 \\
Median & 1 & 1 & $\$ 0$ & 0 & - \\
\hline & & & & &
\end{tabular}

day to day social-ecological and intertidal environmental dynamics. Thus, women have substantial ecological knowledge that could provide updated and essential information in the assessment of coastal change and socioecological vulnerability (Burgos 2016).

Recent national census results suggest that $<5 \%$ of households in Timor-Leste are involved in fishing (General Directorate of Statistics, Timor-Leste 2018), but responses to this question refer to formally recognised fishing sector activities such as handline and gill netting from a vessel, and would likely not have accounted for gleaning or other women's fishing activities. In contrast, FGD results suggest that most households $(>80 \%)$ in a given coastal community conduct gleaning at one time or other indicating that national catch figures could be vastly under representative. Approximately $40 \%$ of the population lives in coastal areas in Timor-Leste. At $\sim 560000$ people with an average household size of 5.3, this would imply that as many as $\sim 84500$ households could be accessing and utilising marine resources to varying frequency. As such, the estimated consumption rates of fish for coastal areas (17.6 kg/capita/year) (AMSAT International 2011) are likely to be significantly underestimated, as well as the figure of national fisheries production. Timor-Leste is not alone. Even in the Pacific islands where gleaning fisheries are visibly important and documented in greater detail, surveys do not effectively capture the landings or consumption from these activities (Gillett 2016).

The impacts of gleaning on reef systems can be substantial and directly contribute to habitat degradation and overfishing (Andréfouët et al. 2013). Currently, fishing pressure is somewhat controlled by poor roads and limited access to ice and refrigeration (López-Angarita et al. 2019). Nearshore areas close to community sites are often chosen for fisheries closures due to ease of enforcement, but interventions rarely assess local legitimacy and transparency with all user groups, such as women fishers (Pomeroy et al. 2015). In countries such as Timor-Leste, 


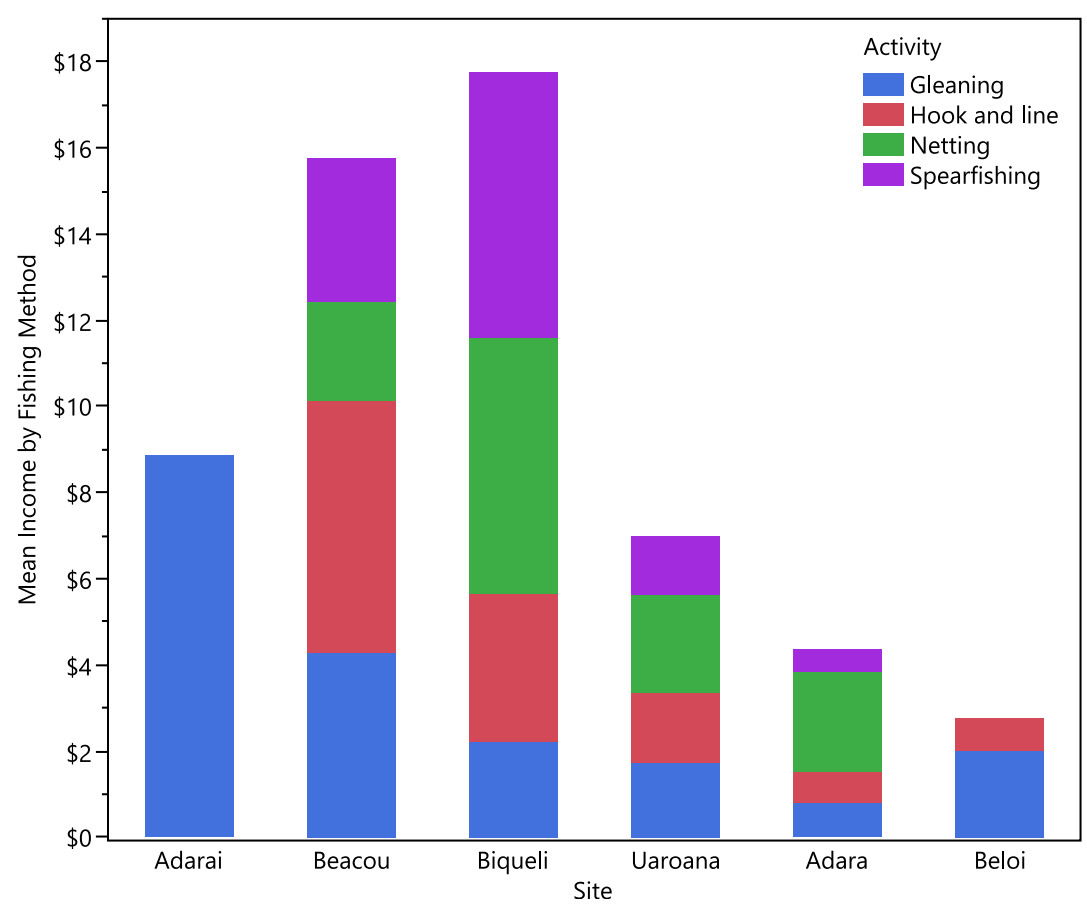

Fig. 5 Mean income of women fishers in six coastal communities of Timor-Leste, stacked by fishing method.

where poverty and malnutrition statistics are some of the highest in the world (von Grebmer et al. 2018), this is likely to have serious consequences for poor and marginalised sectors of society that depend on low-entry-cost fisheries near to their homes. With increasing dependence on reef resources, comes increasing vulnerability of those involved to slide into social-ecological traps (Cole et al. 2018). Co-management processes that involve those affected by management in making management decisions (Berkes 2009) are paramount, and initial examples building on local laws and ritual practice (tara bandu) have shown some success (Tilley et al. 2019a).

Fishers across social groups and communities are not equally vulnerable to management regulations (Tilley et al. 2018), so incorporation of gendered perspectives, priorities, and aspirations is fundamental in achieving equitable, decentralised, co-managed fisheries in Timor-Leste. Addressing power and gender inequities requires the proactive development of women's capacity and confidence to effectively participate in decision-making processes (Mutimukuru-Maravanyika et al. 2017). If investments are made in women's education and capacity according to their aspirations, direct household nutritional gains (Miller et al. 2017) and resource sustainability improvements (Tindall and Holvoet 2008) are feasible. If however, their contributions continue to be invisible and decisions made without their participation, conservation and management initiatives could have disastrous and cascading impacts on household nutrition (Williams 2002; Bennett 2005). The impacts of management and conservation interventions on women's fishing areas have not been thoroughly assessed, but it is clear that empowering women to make decisions is crucial to enable them to protect their fishing grounds (e.g. gleaning areas) for food security (Kleiber et al. 2018), and can have rapid and lasting benefits (Aswani and Weiant 2004; Kleiber et al. 2014).

Our characterisation and preliminary quantification of women's fishing activities highlight the need for genderintegrated instruments in national fisheries monitoring and management. When appropriately quantified, women's fisheries are likely to represent a significant proportion of the SSF production in Timor-Leste. There are clear power asymmetries present at different levels of governance. This study represents the first step towards equitable inclusion of women in marine management and contributes to current initiatives that are building momentum for greater gender equity in small-scale fisheries (FAO 2015, 2017).

Acknowledgements This study was funded by PLAN International UK under the project "Piloting Sustainable Livelihood Interventions in Coastal Timor-Leste", and the "Fisheries Sector Support Program" funded by the Royal Norwegian Embassy in Jakarta, led by WorldFish. Fieldwork and input from $\mathrm{AB}$ was funded by the French National Research Agency (ANR) under the "Cultural policies, local heritage and collaborative approaches project (POPEI-coll) in Insulindia" led by the French Institute of Research for Development (IRD); Input from HE was funded by SwedBio under the project "Enhancing livelihoods while governing marine resources in Pacific Island countries" led by WorldFish We are very grateful to the women who co-generated data through focus groups, interviews and 
data collection, and to the communities and National Fisheries Directorate of the Ministry of Agriculture and Fisheries, Timor-Leste for their ongoing partnership and collaboration.

Author contributions AT, AR and DM designed the study. AD, JRL and AR conducted the focus groups, questionnaires and fieldwork, AT analyzed the data. AT, AB, AD, JRL, HE and DM wrote the manuscript.

Open Access This article is licensed under a Creative Commons Attribution 4.0 International License, which permits use, sharing, adaptation, distribution and reproduction in any medium or format, as long as you give appropriate credit to the original author(s) and the source, provide a link to the Creative Commons licence, and indicate if changes were made. The images or other third party material in this article are included in the article's Creative Commons licence, unless indicated otherwise in a credit line to the material. If material is not included in the article's Creative Commons licence and your intended use is not permitted by statutory regulation or exceeds the permitted use, you will need to obtain permission directly from the copyright holder. To view a copy of this licence, visit http://creativecommons. org/licenses/by/4.0/.

\section{REFERENCES}

Allison, E.H., and D.J. Mills. 2018. Counting the fish eaten rather than the fish caught. Proceedings of the National academy of Sciences of the United States of America 115: 7459-7461.

AMSAT International. 2011. Fish and animal protein consumption and availability in Timor-Leste. Field Project Document 2011/TIM/02. Regional Fisheries Livelihoods Programme for South and Southeast Asia (GCP/RAS/237/SPA).

Andréfouët, S., M.M.M. Guillaume, A. Delval, F.M.A. Rasoamanendrika, J. Blanchot, and J.H. Bruggemann. 2013. Fifty years of changes in reef flat habitats of the Grand Récif of Toliara (SW Madagascar) and the impact of gleaning. Coral Reefs 32: 757-768.

Aswani, S., and P. Weiant. 2004. Scientific evaluation in women's participatory management: Monitoring Marine Invertebrate Refugia in the Solomon Islands. Human organization 63: 301-319.

Beitl, C.M. 2011. Cockles in custody: The role of common property arrangements in the ecological sustainability of mangrove fisheries on the Ecuadorian coast. International Journal of the Commons 5: 485-512.

Béné, C. 2003. When fishery rhymes with poverty: A first step beyond the old paradigm on poverty. World Development 31: 949-975.

Béné, C., R. Arthur, H. Norbury, E.H. Allison, M. Beveridge, S. Bush, L. Campling, W. Leschen, et al. 2016. Contribution of fisheries and aquaculture to food security and poverty reduction: Assessing the current evidence. World Development 79: 177-196.

Bennett, E. 2005. Gender, fisheries and development. Marine Policy 29: 451-459.

Berkes, F. 2009. Evolution of co-management: Role of knowledge generation, bridging organizations and social learning. Journal of Environmental Management 90: 1692-1702.

Bogard, J.R., S. Farook, G.C. Marks, J. Waid, B. Belton, M. Ali, K. Toufique, A. Mamun, et al. 2017. Higher fish but lower micronutrient intakes: Temporal changes in fish consumption from capture fisheries and aquaculture in Bangladesh. PLoS ONE 12: e0175098.

Burgos, A. 2016. Savoirs naturalistes et stratégies de collecte de Geloina erosa, Geloina expansa et Polymesoda bengalensis dans la mangrove de l'île de Siberut (Indonésie). Revue d'ethnoécologie 9: 2-25.

Chapman, M.D. 1987. Women's fishing in Oceania. Human Ecology 15: 267-288.

Charles, A. 2011. Human rights and fishery rights in small-scale fisheries management. In Small-scale Fisheries Management: Frameworks and approaches for the developing world, ed. R.S. Pomeroy and N. Andrew, 59-74. Wallingford: CABI Publishing.

Cole, S., C. McDougall, A. Kaminski, A. Kefi, A. Chilala, and G. Chisule. 2018. Postharvest fish losses and unequal gender relations: Drivers of the social-ecological trap in the Barotse Floodplain fishery. Zambia. Ecology and Society 23: 18.

da Costa, M., M. Lopes, A. Ximenes, A.R. Ferreira, L. Spyckerelle, R. Williams, H. Nesbitt, and W. Erskine. 2013. Household food insecurity in Timor-Leste. Food Security 5: 83-94.

de la Torre-Castro, M., S. Fröcklin, S. Börjesson, J. Okupnik, and N.S. Jiddawi. 2017. Gender analysis for better coastal management-Increasing our understanding of social-ecological seascapes. Marine Policy 83: 62-74.

Eriksson, H., J. Albert, S. Albert, R. Warren, K. Pakoa, and N. Andrew. 2017. The role of fish and fisheries in recovering from natural hazards: Lessons learned from Vanuatu. Environmental Science \& Policy 76: 50-58.

FAO. 2015. Voluntary guidelines for securing sustainable small-scale fisheries in the context of food security and poverty eradication. Rome: Food and Agriculture Organization of the United Nations.

FAO. 2017. Workshop on improving our knowledge on small-scale fisheries: Data needs and methodologies. Workshop proceedings, 27-29 June 2017, Rome, Italy. FAO Fisheries and Aquaculture Proceedings No. 55. Rome, Italy.

Fröcklin, S., M. De La Torre-Castro, E. Håkansson, A. Carlsson, M. Magnusson, and N.S. Jiddawi. 2014. Towards improved management of tropical invertebrate fisheries: Including time series and gender. PLOS ONE. https://doi.org/10.1371/journal.pone. 0091161.

General Directorate of Statistics, Timor-Leste. 2018. Timor-Leste Population and Housing Census 2015 Thematic Report. Volume 12 Analytical Report on Agriculture and Fisheries. GDS, FAO \& UNFPA.

Gillett, R.E. 2009. Fisheries in the Economies of the Pacific Island Countries and Territories. Mandaluyong city: Asian Development Bank.

Gillett, R. E. 2016. Fisheries in the economies of Pacific Island Countries and Territories. SPC.

Golden, C.D., E.H. Allison, W.W.L. Cheung, M.M. Dey, B.S. Halpern, D.J. McCauley, M. Smith, B. Vaitla, et al. 2016. Nutrition: Fall in fish catch threatens human health. Nature 534: 317-320.

Government of Timor-Leste. 2015. Timor-Leste Population and Housing Census 2015.

Harper, S., M. Adshade, V.W.Y. Lam, D. Pauly, and U.R. Sumaila. 2020. Valuing invisible catches: Estimating the global contribution by women to small-scale marine capture fisheries production. PLOS ONE 15: e0228912. https://doi.org/10.1371/journal. pone.0228912.

Harper, S., D. Zeller, M. Hauzer, D. Pauly, and U.R. Sumaila. 2013. Women and fisheries: Contribution to food security and local economies. Marine Policy 39: 56-63.

Hicks, C.C., P.J. Cohen, N.A.J. Graham, K.L. Nash, E.H. Allison, C D’Lima, D.J. Mills, M. Roscher, et al. 2019. Harnessing global fisheries to tackle micronutrient deficiencies. Nature 574: 95-98. 
Hill, H. B. 1978. The use of nearshore marine life as a food resource by American Samoans. PhD, University of Hawii.

Hockey, P.A.R., A.L. Bosman, and W.R. Siegfried. 1988. Patterns and correlates of shellfish exploitation by costal people in Transkei: An enigma of protein production. The Journal of Applied Ecology 25: 353-363.

Kleiber, D., L.M. Harris, and A. Vincent. 2014. Improving fisheries estimates by including women's catch in the Central Philippines. Canadian Journal of Fisheries and Aquatic Sciences [Journal Canadien des Sciences Halieutiques et Aquatiques] 71: 656-664.

Kleiber, D., L. Harris, and A.C.J. Vincent. 2018. Gender and marine protected areas: A case study of Danajon Bank. Philippines. Maritime Studies 17: 163.

Kolding, J. 1989. The fish resources of Lake Turkana and their environment. University of Bergen, Norway. (Scient. Degree in Fisheries Biology).

Lambeth, L., B. Hanchard, H. Aslin, L. Fay-Sauni, P. Tuara, K. Des Rochers, A. Vunisea Source, and W. Jmc. 2014. An overview of the involvement of women in fisheries activities in Oceania. SPC Women in Fisheries Information Bulletin 25: 21-33.

López-Angarita, J., K.J. Hunnam, M. Pereira, D.J. Mills, J. Pant, S.J. Teoh, E.A.L. Eriksson, and A. Tilley. 2019. Fisheries and aquaculture of Timor-Leste in 2019: Current knowledge and opportunities. Penang: WorldFish. https://digitalarchive. worldfishcenter.org/handle/20.500.12348/3737.

Luomala, K. 1980. Some Fishing Customs and Beliefs in Tabiteuea (Gilbert Islands, Micronesia). Anthropos 75: 523-558.

Miller, L.C., N. Joshi, M. Lohani, B. Rogers, S. Mahato, S. Ghosh, and P. Webb. 2017. Women's education level amplifies the effects of a livelihoods-based intervention on household wealth, child diet, and child growth in rural Nepal. International Journal for Equity in Health 16: 1-17.

Mills, D.J., A. Tilley, M. Pereira, and D. Hellebrandt. 2017. Livelihood diversity and dynamism in Timor-Leste; insights for coastal resource governance and livelihood development. Marine Policy 82: 206-215. https://doi.org/10.1016/j.marpol. 2017.04.021.

Mills, D.J., L. Westlund, G. de Graaf, Y. Kura, R. Willman, and K. Kelleher. 2011. Under-reported and undervalued: Small-scale fisheries in the developing world. In Small-scale fisheries management: Frameworks and approaches for the developing world, ed. R.S. Pomeroy and N.L. Andrew, 1-15. Wallingford: CABI.

Molyneux, N., G.R. da Cruz, R.L. Williams, R. Andersen, and N.C. Turner. 2012. Climate change and population growth in Timor Leste: Implications for food security. Ambio 41: 823-840.

Mutimukuru-Maravanyika, T., D.J. Mills, C. Asare, and G.A. Asiedu. 2017. Enhancing women's participation in decision-making in artisanal fisheries in the Anlo Beach fishing community, Ghana. Journal of Water Resources and Rural Development. https://doi. org/10.1016/j.wrr.2016.04.001.

Österblom, H., C.C.C. Wabnitz, D. Tladi et al. 2020. Towards ocean equity. Washington, DC: World Resources Institute. Available online at www.oceanpanel.org/how-distribute-benefits-oceanequitably.

Pomeroy, R., J. Parks, K. Reaugh-Flower, M. Guidote, H. Govan, and S. Atkinson. 2015. Status and priority capacity needs for local compliance and community-supported enforcement of marine resource rules and regulations in the Coral Triangle Region. Coastal Management 43: 301-328.

Quinn, N.J., and M. Tina Davis. 1997. The productivity and public health considerations of the urban women's daytime subsistence fishery Off Suva Peninsula' Fiji. South Pacific Journal of Natural Science 15: 63-92.
Thomas, F.R. 2007. The behavioral ecology of shellfish gathering in Western Kiribati, Micronesia 1: Prey choice. Human Ecology 35: 179-194.

Tilley, A., P. Herrón, S. Espinosa, J. López-Angarita, and S. Box. 2018. Predicting vulnerability to management changes in datalimited, small-scale fisheries. Marine Policy 94: 39-45. https:// doi.org/10.1016/j.marpol.2018.04.013.

Tilley, A., K. Hunnam, D. Mills, D. Steenbergen, H. Govan, E. Alonso-Poblacion, M. Roscher, M. Pereira, et al. 2019a. Evaluating the fit of co-management for small-scale fisheries governance in Timor-Leste. Frontiers in Marine Science 6: 392. https://doi.org/10.3389/fmars.2019.00392.

Tilley, A., S.P. Wilkinson, J. Kolding, J. López-Angarita, M. Pereira, and D.J. Mills. 2019b. Nearshore fish aggregating devices show positive outcomes for sustainable fisheries development in Timor-Leste. Frontiers in Marine Science 6: 487. https://doi. org/10.3389/fmars.2019.00487.

Tindall, C., and K. Holvoet. 2008. From the lake to the plate: Assessing gender vulnerabilities throughout the fisheries chain. Development 51: 205-211.

von Grebmer, J., L. Bernstein, F. Hammond, A. Patterson, L. Sonntag, J. Klaus, O. Fahlbusch, C. Towey, et al. 2018. Global Hunger Index: Forced Migration and Hunger. Welthungerhilfe and Concern Worldwide.

Waselkov, G.A. 1987. 3-Shellfish gathering and shell midden archaeology. In Advances in archaeological method and theory, ed. M.B. Schiffer, 93-210. San Diego: Academic Press.

Weeratunge, N., C. Béné, R. Siriwardane, A. Charles, D. Johnson, E.H. Allison, P.K. Nayak, and M.C. Badjeck. 2014. Small-scale fisheries through the wellbeing lens. Fish and Fisheries 15: 255-279.

Williams, S. B. 2002. Making each and every African fisher count: Women do fish. In Global Symposium on Women in Fisheries. ICLARM - WorldFish.

Publisher's Note Springer Nature remains neutral with regard to jurisdictional claims in published maps and institutional affiliations.

\section{AUTHOR BIOGRAPHIES}

Alexander Tilley $(\bowtie)$ is a Scientist at WorldFish. His research focuses on enhancing fisher livelihoods and environmental sustainability, specifically through the application of technology and data systems to improve monitoring and management.

Address: WorldFish Timor-Leste, Ministry of Agriculture and Fisheries, Av. Nicolao Lobato, No. 5, Comoro, Dili, Timor-Leste.

Address: WorldFish, Jalan Batu Maung, Batu Maung, 11960 Bayan

Lepas, Penang, Malaysia.

e-mail: alex.tilley@gmail.com

Ariadna Burgos is a postdoctoral researcher at the French Institute of Research for Development (IRD). Her research focuses on socioecological dynamics of coastal ecosystems and the evolution of artisanal fisheries. She has developed a novel approach to the study of human and molluscs interactions that combines qualitative and quantitative approaches from different disciplines such as anthropology, ecology and archaeology.

Address: Muséum National d'Histoire Naturelle, Département Homme \& Environnement, Laboratoire Patrimoines locaux, Environnement et Globalisation (PALOC), French National Research Institute for Sustainable Development (IRD), ANR Popei-Coll, UMR 208 Paloc (IRD-MNHN), CP 135 - 57, rue Cuvier, 75231 Paris Cedex 05, France.

e-mail: ariadna.burgos@mnhn.fr 
Agustinha Duarte is a Research Analyst at WorldFish Timor-Leste. Her research interests are applying social science techniques to build resilient small-scale fisheries in Timor-Leste with a focus on gender, livelihood, value chains, nutrition and food security.

Address: WorldFish Timor-Leste, Ministry of Agriculture and Fisheries, Av. Nicolao Lobato, No. 5, Comoro, Dili, Timor-Leste.

e-mail: a.duarte@cgiar.org

Joctan dos Reis Lopes Lopes is a research analyst working with WorldFish Timor-Leste. His research interests include fisheries data management, marine ecology and conservation, and natural resource management.

Address: WorldFish Timor-Leste, Ministry of Agriculture and Fisheries, Av. Nicolao Lobato, No. 5, Comoro, Dili, Timor-Leste.

e-mail: J.DosReisLopes@cgiar.org

Hampus Eriksson is a Senior Scientist at WorldFish, a CGIAR Research Center, and Associate Professor at the Australian Centre for Ocean Resources and Security (ANCORS) at the University of Wollongong, Australia. His research focuses on coastal livelihoods and the participatory testing of innovations that enhance fish-based livelihoods in small-scale fisheries and is implemented through crossdisciplinary collaborations in the academic and fisheries sector in
Africa, Southeast Asia and the Pacific Islands.

Address: WorldFish, Jalan Batu Maung, Batu Maung, 11960 Bayan Lepas, Penang, Malaysia.

Address: Australian National Centre for Ocean Resources and Security (ANCORS), University of Wollongong, Squires Way, Wollongong, NSW 2500, Australia.

e-mail: h.eriksson@cgiar.org

David Mills is a fisheries ecologist, senior scientist with WorldFish, adjunct Principal Research Fellow at the ARC Centre of Excellence for Coral Reef Studies, James Cook University, and is Research Lead for the WorldFish program in Timor-Leste. His research has a broad focus on fisheries sustainability for food and nutrition security and recent work has covered policy development, approaches to comanagement, sustainable coastal livelihoods and fish in food systems. He has worked widely in the developing world including West Africa, south-east Asia and the Pacific.

Address: WorldFish, Jalan Batu Maung, Batu Maung, 11960 Bayan Lepas, Penang, Malaysia.

Address: Australian Research Council Centre of Excellence for Coral Reef Studies, James Cook University, Douglas, Australia.

e-mail: d.mills@cgiar.org 